\title{
TITLE: Comparison of horizontal corneal diameter measurements using Orbscan IIz, OPD Scan III, and IOLMaster 700
}

Sebastian Cruz, MD ${ }^{1}$, Felipe Valenzuela, MD, ${ }^{1,2}$, Juan Stoppel, MD ${ }^{1}$, Eugenio Maul, MD, $\mathrm{MPH}^{1}$, Allister Gibbons, $\mathrm{MD}^{3}$

${ }^{1}$ Fundación Oftalmológica Los Andes, Santiago, Chile

${ }^{2}$ Department of Ophthalmology - Clinica Universidad de los Andes Los Andes, Santiago, Chile.

${ }^{3}$ Department of Ophthalmology - Bascom Palmer Eye Institute, University of Miami, Miller School of Medicine, Miami, FL, USA.

\section{Conflict of Interest:}

The author(s) have no proprietary or commercial interest in any material discussed in this article.

\section{Corresponding Author:}

Felipe Valenzuela, MD

Assistant Professor of Ophthalmology Universidad de los Andes

Fundacion Oftalmologica Los Andes

Las Hualtatas 5951, Vitacura, Santiago, Chile. Postal code: 7650710

Phone: (56) 2 23704635; Mobile: (56) 995460719

E-mail: felipevalenz@gmail.com

Word count: 2,166 
medRxiv preprint doi: https://doi.org/10.1101/2020.05.21.20109488; this version posted May 25, 2020. The copyright holder for this preprint (which was not certified by peer review) is the author/funder, who has granted medRxiv a license to display the preprint in perpetuity.

All rights reserved. No reuse allowed without permission.

\section{ABSTRACT}

Purpose: To compare 3 automated devices for measuring the horizontal corneal diameter [white-to-white (WTW) distance].

Setting: Fundacion Oftalmologica Los Andes, Santiago, Chile.

Study Design: Retrospective.

Methods: In 65 eyes of 38 patients, the WTW distance was measured independently using Orbscan IIz tomography system (Bausch \& Lomb), IOLMaster 700 (Carl Zeiss Meditec) and OPD Scan III (NIDEK). We tested for systematic differences in measurements and estimated the limits of agreement (LoA) using linear mixed effects models.

Results The mean WTW distance was $11.8 \pm 0.40 \mathrm{~mm}$ with Orbscan IIz, $12.1 \pm 0.5 \mathrm{~mm}$ with IOLMaster 700 and $12.0 \pm 0.4 \mathrm{~mm}$ with OPD Scan III. The mean difference between IOLMaster 700 and Orbscan IIz was 0.33 (95\% CI 0.28;0.38) ( $<<0.001)$, between OPD Scan III and Orbscan IIz was $0.24 \mathrm{~mm}(95 \%$ CI $0.21 ; 0.28)(\mathrm{p}<0.001)$, and between IOL Master 700 and OPD Scan III was 0.09 (95\% CI 0.05;0.12) $(\mathrm{p}<0.001)$. The 95\% LoA for Orbscan IIz versus IOLMaster 700 was $-0.69 \mathrm{~mm}$ to $0.03 \mathrm{~mm}$, Orbscan IIz versus OPD Scan III was $-0.52 \mathrm{~mm}$ to $-0.03 \mathrm{~mm}$, and OPD versus IOLMaster 700 was $-0.39 \mathrm{~mm}$ to $0.22 \mathrm{~mm}$. Switching to IOLMaster 700 or OPD Scan III measurements led to a selection of a longer phakic IOL length (Visian ICL, STAAR) in $34 \%$ and $33 \%$ of the cases, respectively compared to Orbscan IIz.

Conclusions: The data suggests that these devices are not interchangeable for usual clinical practice. Adjustments based on mean differences was not enough to compensate for interinstrument discrepancy in WTW measurements.

Key words: corneal diameter, white-to-white distance, Orbscan IIz, IOLMaster 700, OPD Scan III 
medRxiv preprint doi: https://doi.org/10.1101/2020.05.21.20109488; this version posted May 25, 2020. The copyright holder for this preprint (which was not certified by peer review) is the author/funder, who has granted medRxiv a license to display the preprint in perpetuity.

All rights reserved. No reuse allowed without permission.

\section{INTRODUCTION}

The horizontal corneal diameter, also known as white to white (WTW) distance is the measurement between the limbus from one side of the cornea to the other and is essential for sizing calculation of the Implantable Collamer Lens (ICL) posterior chamber phakic intraocular lens (pIOL) (STAAR Surgical, Monrovia, California). ${ }^{1-3}$ Many postoperative complications associated with posterior chamber phakic IOL surgery are related to suboptimal lens sizing. ${ }^{4,5}$ An oversized lens can cause angle closure or iris chafing leading to pigment dispersion, whereas an undersized lens can accelerate anterior subcapsular cataract formation or cause zonular damage with subsequent dislocation of the pIOL. ${ }^{4-7}$

The lens sizing protocol originally approved by the United States Food and Drug Administration (FDA) requires adding $0.5 \mathrm{~mm}$ to the to the horizontal white-to-white measurement obtained using calipers at a slit lamp or using the Orbscan unit (Bausch \& Lomb, Rochester, NY). ${ }^{1}$ There are manual and automated methods of WTW distance measurement. ${ }^{8-10}$ Manual methods include millimeter rules, photography, calipers, and the direct beam of slit lamp in coaxial position. ${ }^{11,12}$ Automated methods, like the ones compared in this study, use computerized video limbus detection through digital gray-scale and have been associated to reduced inter-operator variability and greater accuracy. ${ }^{11}$

Comparison studies including tomographers such as the Orbscan IIz and Pentacam HR (Oculus, Wetzlar, Germany) have determined a high level of correlation, and some authors have even suggested that the data can be used interchangeably in clinical practice. ${ }^{13}$ However, studies comparing other instruments: IOLMaster 500 (Carl Zeiss Meditec, Jena, Germany), LenStar 900 
medRxiv preprint doi: https://doi.org/10.1101/2020.05.21.20109488; this version posted May 25, 2020. The copyright holder for this preprint (which was not certified by peer review) is the author/funder, who has granted medRxiv a license to display the preprint in perpetuity.

All rights reserved. No reuse allowed without permission.

(HaagStreit, Wedel, Germany), Pentacam HR, Visante OCT (Carl Zeiss Meditec) have shown that measurements are not interchangeable. ${ }^{14}$ The IOLMaster 700 (Carl Zeiss Meditec AG, Jena, Germany), which was the first commercially available swept source optical coherence tomography (SS-OCT) based biometer, was introduced in 2015 in the USA. To the best of our knowledge there are no studies comparing the WTW distance between IOL Master 700 and Orbscan IIz, neither between the OPD Scan III aberrometer (Nidek, Gamagori, Japan) versus other automated instruments.

The purpose of this study was to compare automated horizontal corneal diameter (WTW distance) measurements using the IOLMaster 700, OPD Scan III and Orbscan IIz and to determine the agreement between them.

\section{SUBJECTS AND METHODS}

\section{Patients}

This study consisted of a single-center retrospective review of patients who were evaluated for refractive surgery with 3 different automated WTW measurements: Orbscan IIz, OPD Scan III and IOL Master 700. The measurements were performed independently by 3 examiners on the same visit day. This study was conducted at Fundación Oftalmológica Los Andes (Santiago, Chile), this study was approved by our institution's Ethics Committee and adhered to the tenets of the Declaration of Helsinki. Patients with known limbal pathology, previous ocular surgery, trauma or anatomical corneal alterations were excluded. Cases with evident failure of the automated segmentation algorithm for any of the 3 instruments were also excluded. 
medRxiv preprint doi: https://doi.org/10.1101/2020.05.21.20109488; this version posted May 25, 2020. The copyright holder for this preprint (which was not certified by peer review) is the author/funder, who has granted medRxiv a license to display the preprint in perpetuity.

All rights reserved. No reuse allowed without permission.

\section{Instruments}

The Orbscan IIz device combines the Placido rings and slit-scanning method to improve the precision of topographic measurements. The device provides data on corneal topography, corneal thickness, and anterior chamber depth. A digital gray-scale image of the anterior segment is reconstructed from 140 slit images. The computer automatically detects the cornea by comparing grayscale steps and calculates the horizontal corneal diameter. ${ }^{13}$

The IOLMaster 700 is the first SS-OCT-based biometry that measures a longitudinal section of the eye (AL, anterior chamber depth, corneal central thickness, lens thickness) based on SS-OCT with the exception of WTW, which is measured using the light-emitting diode light source determined by iris configuration, and keratometry, which is measured using 2.5-m zone telecentric keratometry. For WTW measurements, the limbus is detected automatically by a digital gray-scale photograph of the anterior eye segment is taken after focusing on the iris. ${ }^{15,16}$ The OPD Scan III is capable of detecting the limbus, in a similar way to Orbscan IIz. It allows the measurement of WTW distance in mesopic and scotopic conditions. The latter is an important aspect, considering that the measurement uses grayscale that is affected by the brightness. ${ }^{17}$

\section{Measurements}

Measurements were obtained, for each patient, during the same day. These were performed by 3 different certified and qualified operators that were not aware of the results obtained by the other 2 instruments. If necessary, imaging was repeated until exams with acceptable quality were obtained. If accurate images for any of these modalities were not obtained, for a given eye, that eye was excluded from the study. Furthermore, any patient whose values had to be manually 
medRxiv preprint doi: https://doi.org/10.1101/2020.05.21.20109488; this version posted May 25, 2020. The copyright holder for this preprint (which was not certified by peer review) is the author/funder, who has granted medRxiv a license to display the preprint in perpetuity.

All rights reserved. No reuse allowed without permission.

adjusted were not included in the study. In the Orbscan IIz, the automatically detected edge of the cornea is displayed with a green broken line, although this equipment discards low quality images, in some cases, measurement errors related to limbus recognition can occur. For the measurement of IOLMaster 700, all the manufacturer's instructions were followed. Measurements that were qualified as "Borderline value!" (uncertain value) were excluded. In OPD Scan III, the calculated corneal diameter is displayed in a similar way to the Orbscan IIz. To avoid bias and to standardize the conditions for all measurements, all tests were done under mesopic conditions.

\section{Statistical Analysis}

Statistical analysis and plotting was performed using Stata version 13 (StataCorp College Station, Texas) and R 3.6 (www.r-project.com, Vienna Austria). To account for the correlation of measurements of patients in which right and left eyes were included, linear mixed effects models were used to test for systematic measurement differences between methods and estimate limits of agreement. Bland-Altman plots with 95\% LoA were used to display inter-instrument measurement differences and limits of agreement. The McNemar test was used to compare de size miss-selection between IOLMaster 700 and OPD Scan III vs Orbscan IIz.

\section{RESULTS}

Data from 78 eyes of 47 refractive surgery candidates were reviewed. A total of 13 eyes were excluded due to measurement error (failure of automated segmentation or unreliable exams), leaving 65 eyes of 38 patients for analysis. Ocular characteristics are shown in Table 1. 
medRxiv preprint doi: https://doi.org/10.1101/2020.05.21.20109488; this version posted May 25, 2020. The copyright holder for this preprint (which was not certified by peer review) is the author/funder, who has granted medRxiv a license to display the preprint in perpetuity. All rights reserved. No reuse allowed without permission.

Table 1. Patients characteristics by laterality, axial length and anterior chamber depth.

$\begin{array}{lc} & \text { Number } \\ \text { Eyes, } \mathbf{n}(\%) & 65(100) \\ \quad \text { Right } & 34(52) \\ \text { Left } & 31(48) \\ \text { AL mean, mm (SD) } & 26(3) \\ \text { AL, n (\%) } & \\ \quad<24 \text { mm } & 15(23) \\ >26 \text { mm } & 35(54) \\ 24-26 \text { mm } & 15(23) \\ \text { ACD mean, mm (SD) } & 3.4(0.4) \\ \text { ACD, n }(\%) & 37(57) \\ \quad<3.5 \mathrm{~mm} & 28(43) \\ >=3.5 \mathrm{~mm} \\ \text { SD= standard deviation, mm= millimeters, } \mathrm{AL}=\text { axial length, ACD= anterior chamber depth }\end{array}$

Excluded cases can be divided as follows: Orbscan IIz (4 eyes, 2 patients), OPD Scan III (7 eyes, 5 patients), IOLMaster 700 (2 eyes, 2 patients). The mean WTW distance measurement obtained with Orbscan IIz, OPD Scan III and IOLMaster 700 were $11.8 \pm 0.4 \mathrm{~mm}, 12.0 \pm 0.4 \mathrm{~mm}$ and $12.1 \pm 0.5 \mathrm{~mm}$, respectively. Table 2 shows WTW measurements according to gender, laterality, axial length (AL) and anterior chamber depth (ACD).

Table 2. Mean WTW distance by gender, laterality, axial length and anterior chamber depth.

$\begin{array}{llcccc} & \begin{array}{c}\text { IOL Master 700 } \\ \text { mm (SD) }\end{array} & \begin{array}{c}\text { OPD Scan III } \\ \mathbf{m m}(\text { SD) }\end{array} & \begin{array}{c}\text { Orbscan IIz } \\ \mathbf{m m}(\text { SD) }\end{array} & \text { p value } & \text { Total (n) } \\ \text { Overall } & 12.1(0.5) & 12.0(0.4) & 11.8(0.4) & 1.00 \mathrm{E}-04 & 65 \\ \text { Right eye } & 12.0(0.5) & 12.0(0.4) & 11.7(0.4) & 0.0074 & 34 \\ \text { Left eye } & 12.1(0.5) & 12.0(0.5) & 11.8(0.4) & 0.0118 & 31 \\ \text { Male } & 12.2(0.4) & 12.1(0.4) & 11.8(0.4) & 0.0045 & 24 \\ \text { Female } & 12.0(0.5) & 11.9(0.4) & 11.7(0.4) & 0.0121 & 41 \\ \text { AL <24 mm } & 12.0(0.4) & 11.8(0.4) & 11.7(0.4) & 0.1564 & 15 \\ \text { AL 24-26 mm } & 12.3(0.5) & 12.2(0.4) & 11.9(0.4) & 0.1008 & 15 \\ \text { AL >26 mm } & 12.1(0.5) & 12.0(0.4) & 11.7(0.4) & 0.0037 & 35\end{array}$


medRxiv preprint doi: https://doi.org/10.1101/2020.05.21.20109488; this version posted May 25, 2020. The copyright holder for this preprint (which was not certified by peer review) is the author/funder, who has granted medRxiv a license to display the preprint in perpetuity.

All rights reserved. No reuse allowed without permission.

$\begin{array}{llllll}\mathrm{ACD}<3.5 \mathrm{~mm} & 12.0(0.4) & 11.9(0.4) & 11.7(0.4) & 0.0034 & 37 \\ \mathrm{ACD}>=3.5 \mathrm{~mm} & 12.3(0.5) & 12.2(0.5) & 11.9(0.4) & 0.0091 & 28\end{array}$

$\mathrm{SD}=$ standard deviation, $\mathrm{mm}=$ millimeters, $\mathrm{AL}=$ axial length, $\mathrm{ACD}=$ anterior chamber depth

Figure 1 shows Bland-Altman plots for the 3 compared instruments. Inter-instrument differences do not vary significantly in magnitude or dispersion across the range of WTW values included.

The mean difference between IOLMaster 700 and Orbscan IIz was 0.33 (95\% CI $0.28 ; 0.38$ ) $(\mathrm{p}<0.001)$. The mean difference between OPD Scan III and Orbscan IIz was $0.24 \mathrm{~mm}(95 \%$ CI $0.21 ; 0.28)(\mathrm{p}<0.001)$. All comparisons showed a statistically significant difference between these machines, with the IOLMaster 700 always measuring longer (Table 3).

Table 3. Mean difference and $95 \%$ confidence interval in corneal diameter measurements for Orbscan IIz, OPD Scan III and IOLMaster 700.

$\begin{array}{ccc}\text { Measurement } & \text { Mean difference, } \mathbf{m m}(\mathbf{9 5} \% \mathbf{C I}) & \text { p value } \\ \text { Orbscan-OPD } & -0.24(-0.21 ;-0.28) & <0.01 \\ \text { Orbscan-IOL700 } & -0.33(-0.28 ;-0.38) & <0.01 \\ \text { OPD-IOL700 } & -0.09(-0.05,-0.12) & <0.01\end{array}$

$\mathrm{CI}=$ confidence interval, $\mathrm{mm}$ : millimeters

The $95 \%$ limits of agreement for IOLMaster 700 vs Orbscan IIz (0.03 to $-0.69 \mathrm{~mm})$ were wider than the other comparisons (Figure $1 \&$ Table 4).

Table 4. Mean difference and limits of agreement in corneal diameter measurements for Orbscan IIz, OPD Scan III and IOLMaster 700.

\begin{tabular}{ccc} 
Measurement & Mean Difference $(\mathbf{m m})$ & $\mathbf{9 5 \%}$ of LoA $(\mathbf{m m})$ \\
\hline Orbscan-OPD & -0.24 & $-0.52,-0.03$ \\
Orbscan-IOL700 & -0.33 & $-0.69,0.03$ \\
\hline
\end{tabular}


medRxiv preprint doi: https://doi.org/10.1101/2020.05.21.20109488; this version posted May 25, 2020. The copyright holder for this preprint (which was not certified by peer review) is the author/funder, who has granted medRxiv a license to display the preprint in perpetuity.

$\begin{array}{lll}\text { OPD-IOL700 } & -0.09 & -0.39,0.22\end{array}$

$\mathrm{mm}=$ millimeters, LoA=limits of agreement

Using the STAAR surgical and ordering system OCOS ${ }^{\mathrm{TM}}$ website (https://evoocos.staarag.ch/Live/) we calculated ICL size based on Orbscan IIz, IOLMaster 700 and OPD III. Comparing the current recommended method of using WTW measurements obtained with Orbscan IIz to IOLMaster 700 WTW measurements, resulted in a longer lens length recommendation in $33.9 \%$ of the cases. Similarly, using the OPD Scan III WTW measurements resulted in a longer lens length recommendation in $32.3 \%$ of the cases.

Adjusting IOLMaster 700 and OPD Scan III WTW measurements, using the mean difference obtained in this study, led to a reduction in the discrepancy in calculated lens length. For IOLMaster $700,21.5 \%$ of lenses had a different length compared to Orbscan IIz lens size estimation. For OPD Scan III, 20\% of lenses had a different length compared to Orbscan IIz lens size estimation. Details of the lens length discrepancy before and after adjustment are depicted in Figure 2.

\section{DISCUSSION}

The present study shows that the mean WTW distance readings with the IOLMaster 700 and the OPD Scan III are greater than those obtained with the Orbscan IIz, respectively. This difference was $0.33 \mathrm{~mm}$ and $0.24 \mathrm{~mm}$ in the case of the IOLMaster 700 and OPD Scan III, respectively. This would have had an impact in pIOL ICL selection, in over a $30 \%$ of cases, potentially leading to an increased rate of complications. 
medRxiv preprint doi: https://doi.org/10.1101/2020.05.21.20109488; this version posted May 25, 2020. The copyright holder for this preprint (which was not certified by peer review) is the author/funder, who has granted medRxiv a license to display the preprint in perpetuity.

All rights reserved. No reuse allowed without permission.

The manufacturer's current recommended automated method for measuring the WTW in ICL candidates is based on Orbscan IIz. ${ }^{1}$ This has been studied extensively, and its acceptable accuracy, reproducibility and good clinical outcomes have already been reported. ${ }^{18}$ To the best of our knowledge this is the first study comparing Orbscan IIz to the new swept source IOLMaster 700 and to OPD Scan III. According to our last search (MEDLINE browsing performed on April $30^{\text {th }}, 2020$ ), there were no publications regarding the interchangeability of WTW distance measurements obtained with the IOLMaster 700 or OPD Scan III and Orbscan IIz.

The $95 \%$ LoA for IOLMaster 700 versus Orbscan IIz obtained in our study were $-0.69 \mathrm{~mm}$ to $0.03 \mathrm{~mm}$, considerably wider than $95 \%$ LoA for Pentacam HR versus Orbscan IIz (-0.14 to 0.33 $\mathrm{mm}$; mean difference $0.10 \mathrm{~mm}$ ) reported by Salouti et al, but lower than Galilei versus Orbscan IIz $\quad(-0.72$ to $1.48 \mathrm{~mm}$, mean difference 0.38$)$ reported previously by the same group. ${ }^{13,19}$

In a previous publication by Baumeister et al using the IOLMaster 500 the mean WTW distance difference was approximately $0.24 \mathrm{~mm}$ longer with the IOLMaster 500 than with the Orbscan IIz. The 95\% LoA reported for the IOLMaster 500 versus Orbscan IIz were -0.41 to 0.9 (LoA higher than our study). ${ }^{11}$ Kohnen et al, showed a mean difference of $0.32 \mathrm{~mm}$ higher with the IOLMaster 500 versus Orbscan IIz, and 95\% LoA between 0.1 to $0.54 \mathrm{~mm}$ (LoA which were lower than the ones found in our study). ${ }^{12}$

Interestingly, in the present study OPD Scan III was the equipment that excluded the largest number of patients due to measurement errors. This suggests that it could have more difficulties in detecting the limbus compared to the other two methods. Therefore, we recommend carefully 
medRxiv preprint doi: https://doi.org/10.1101/2020.05.21.20109488; this version posted May 25, 2020. The copyright holder for this preprint (which was not certified by peer review) is the author/funder, who has granted medRxiv a license to display the preprint in perpetuity.

All rights reserved. No reuse allowed without permission.

reviewing the readings obtained to be sure that the automatically detected edge of the cornea is displayed correctly.

According to our results, IOLMaster 700, OPD Scan III and Orbscan IIz cannot be used interchangeably, as the differences between them can be as great as $0.72 \mathrm{~mm}$ (Orbscan IIz/IOL Master 700), $0.55 \mathrm{~mm}$ (OPD Scan III/IOL Master 700) and $0.61 \mathrm{~mm} . \backslash$ (Orbscan IIz/OPD Scan III). Ophthalmologists who routinely use other automated instruments to measure WTW distance for posterior chamber pIOL implantations should consider existing differences between these instruments in their routine clinical practice.

ICL size selection is critical since it is directly related to postoperative vault which is defined as the distance between the anterior surface of the crystalline lens and the posterior surface of the ICL. This is crucial in avoiding adverse events; overvaulting, which can result in elevated intraocular pressure (IOP), glaucoma, endothelial cell loss, and pupil distortion; and low vaulting, which can accelerate cataract formation. ${ }^{4,5,7}$ All these complications can lead to the removal of the phakic lens, its replacement with an ICL of a more appropriate size, or even the need to render the patient pseudophakic.

One of the most commonly methods used to predict ICL postoperative vault is the WTW distance, which is used as a proxy for sulcus-to-sulcus (STS) distance. It has been proposed that direct STS measurement would be more accurate as there are studies that shown low to no correlation between WTW and STS dimensions. ${ }^{20,21}$ However, methods to evaluate STS dimension are not widely available, are operator dependent and have not been conclusive to improve postoperative vault values. ${ }^{22}$ With STS still not approved by the FDA and widespread 
medRxiv preprint doi: https://doi.org/10.1101/2020.05.21.20109488; this version posted May 25, 2020. The copyright holder for this preprint (which was not certified by peer review) is the author/funder, who has granted medRxiv a license to display the preprint in perpetuity.

All rights reserved. No reuse allowed without permission.

non-availability of ultrasound biomicroscopy among refractive surgeons, the current search is towards instruments that can give the ideal WTW for estimating the ICL sizing with accuracy.

Dougherty et al and Kojima et al reported regression equations to calculate optimal ICL size. ${ }^{23,24}$ They used STS, ICL power, ACD and distance between STS plane and anterior crystalline lens surface as possible variables, leading to improved vaulting outcomes. ${ }^{23,24}$ More studies are needed for evaluating accuracy and reliability of these models, which have not been validated by the manufacturer. Future refinement of these models may allow improvement in vault outcomes, thereby decreasing the adverse event rate in these patients.

There are several limitations in this study. First, all selected patients had normal corneas, so these results cannot be extrapolated to patients with corneal abnormalities. Second, this is a retrospective study and although those who performed the exams were qualified, only automated measurements with no errors were considered for evaluation.

In summary, WTW distance was on average shorter when measured with Orbscan IIz, followed by OPD Scan III and finally IOLMaster 700. However, our data does not support that raw or adjusted WTW measurements can be used interchangeably for pIOL ICL size calculation. 


\section{REFERENCES}

1. Sanders DR, Vukich JA, Doney K, et al. U.S. Food and Drug Administration clinical trial of the Implantable Contact Lens for moderate to high myopia. Ophthalmology. $2003 ; 110(2): 255-266$.

2. Seo JH, Kim MK, Wee WR, et al. Effects of white-to-white diameter and anterior chamber depth on implantable collamer lens vault and visual outcome. J Refract Surg. 2009;25(8):730-738.

3. Werner L, Izak AM, Pandey SK, et al. Correlation between different measurements within the eye relative to phakic intraocular lens implantation. J Cataract Refract Surg. 2004;30(9):1982-1988.

4. Fernandes P, Gonzalez-Meijome JM, Madrid-Costa D, et al. Implantable collamer posterior chamber intraocular lenses: a review of potential complications. J Refract Surg. 2011;27(10):765-776.

5. Packer M. Meta-analysis and review: effectiveness, safety, and central port design of the intraocular collamer lens. Clin Ophthalmol. 2016;10:1059-1077. 
medRxiv preprint doi: https://doi.org/10.1101/2020.05.21.20109488; this version posted May 25, 2020. The copyright holder for this preprint (which was not certified by peer review) is the author/funder, who has granted medRxiv a license to display the preprint in perpetuity.

All rights reserved. No reuse allowed without permission.

6. Gimbel HV, Condon GP, Kohnen T, et al. Late in-the-bag intraocular lens dislocation: incidence, prevention, and management. J Cataract Refract Surg. 2005;31(11):21932204.

7. Mastropasqua L, Toto L, Nubile M, et al. Long-term complications of bilateral posterior chamber phakic intraocular lens implantation. J Cataract Refract Surg. 2004;30(4):901904.

8. Guell JL, Morral M, Kook D, et al. Phakic intraocular lenses part 1: historical overview, current models, selection criteria, and surgical techniques. J Cataract Refract Surg. 2010;36(11):1976-1993.

9. Pinero DP, Plaza Puche AB, Alio JL. Corneal diameter measurements by corneal topography and angle-to-angle measurements by optical coherence tomography: evaluation of equivalence. J Cataract Refract Surg. 2008;34(1):126-131.

10. Price FW, Parker DA. Horizontal corneal diameter and its implications for implanting sulcus-fixated lenses. J Cataract Refract Surg. 1997;23(8):1131-1132.

11. Baumeister M, Terzi E, Ekici Y, et al. Comparison of manual and automated methods to determine horizontal corneal diameter. J Cataract Refract Surg. 2004;30(2):374-380.

12. Kohnen $\mathrm{T}$, Thomala MC, Cichocki M, et al. Internal anterior chamber diameter using optical coherence tomography compared with white-to-white distances using automated measurements. J Cataract Refract Surg. 2006;32(11):1809-1813.

13. Salouti R, Nowroozzadeh MH, Zamani M, et al. Comparison of Horizontal corneal diameter measurements using the Orbscan IIz and Pentacam HR systems. Cornea. 2013;32(11):1460-1464. 
medRxiv preprint doi: https://doi.org/10.1101/2020.05.21.20109488; this version posted May 25, 2020. The copyright holder for this preprint (which was not certified by peer review) is the author/funder, who has granted medRxiv a license to display the preprint in perpetuity. All rights reserved. No reuse allowed without permission.

14. Shajari M, Lehmann UC, Kohnen T. Comparison of Corneal Diameter and Anterior Chamber Depth Measurements Using 4 Different Devices. Cornea. 2016;35(6):838-842.

15. Akman A, Asena L, Gungor SG. Evaluation and comparison of the new swept source OCT-based IOLMaster 700 with the IOLMaster 500. $\mathrm{Br} J$ Ophthalmol. 2016;100(9):1201-1205.

16. Cho YJ, Lim TH, Choi KY, et al. Comparison of Ocular Biometry Using New Sweptsource Optical Coherence Tomography-based Optical Biometer with Other Devices. Korean J Ophthalmol. 2018;32(4):257-264.

17. Asgari S, Hashemi H, Jafarzadehpur E, et al. OPD-Scan III: a repeatability and interdevice agreement study of a multifunctional device in emmetropia, ametropia, and keratoconus. Int Ophthalmol. 2016;36(5):697-705.

18. Wang L, Auffarth GU. White-to-white corneal diameter measurements using the eyemetrics program of the Orbscan topography system. Dev Ophthalmol. 2002;34:141146.

19. Salouti R, Nowroozzadeh MH, Zamani M, et al. Comparison of horizontal corneal diameter measurements using Galilei, EyeSys and Orbscan II systems. Clin Exp Optom. 2009;92(5):429-433.

20. Reinstein DZ, Archer TJ, Silverman RH, et al. Correlation of anterior chamber angle and ciliary sulcus diameters with white-to-white corneal diameter in high myopes using artemis VHF digital ultrasound. J Refract Surg. 2009;25(2):185-194.

21. Reinstein DZ, Lovisolo CF, Archer TJ, et al. Comparison of postoperative vault height predictability using white-to-white or sulcus diameter-based sizing for the visian implantable collamer lens. J Refract Surg. 2013;29(1):30-35. 
medRxiv preprint doi: https://doi.org/10.1101/2020.05.21.20109488; this version posted May 25, 2020. The copyright holder for this preprint

(which was not certified by peer review) is the author/funder, who has granted medRxiv a license to display the preprint in perpetuity.

All rights reserved. No reuse allowed without permission.

22. Ghoreishi M. Correlation between Preoperative Sizing of Implantable Collamer Lens (ICL) by White-to-white and Sulcus-to-sulcus Techniques, and Postoperative Vault Size Measured by Sheimpflug Imaging. J Clin Exp Ophthalmol. 2014;5(4):351.

23. Dougherty PJ, Rivera RP, Schneider D, et al. Improving accuracy of phakic intraocular lens sizing using high-frequency ultrasound biomicroscopy. J Cataract Refract Surg. 2011;37(1):13-18.

24. Kojima T, Yokoyama S, Ito M, et al. Optimization of an implantable collamer lens sizing method using high-frequency ultrasound biomicroscopy. Am J Ophthalmol. 2012;153(4):632-637, 637.e631. 

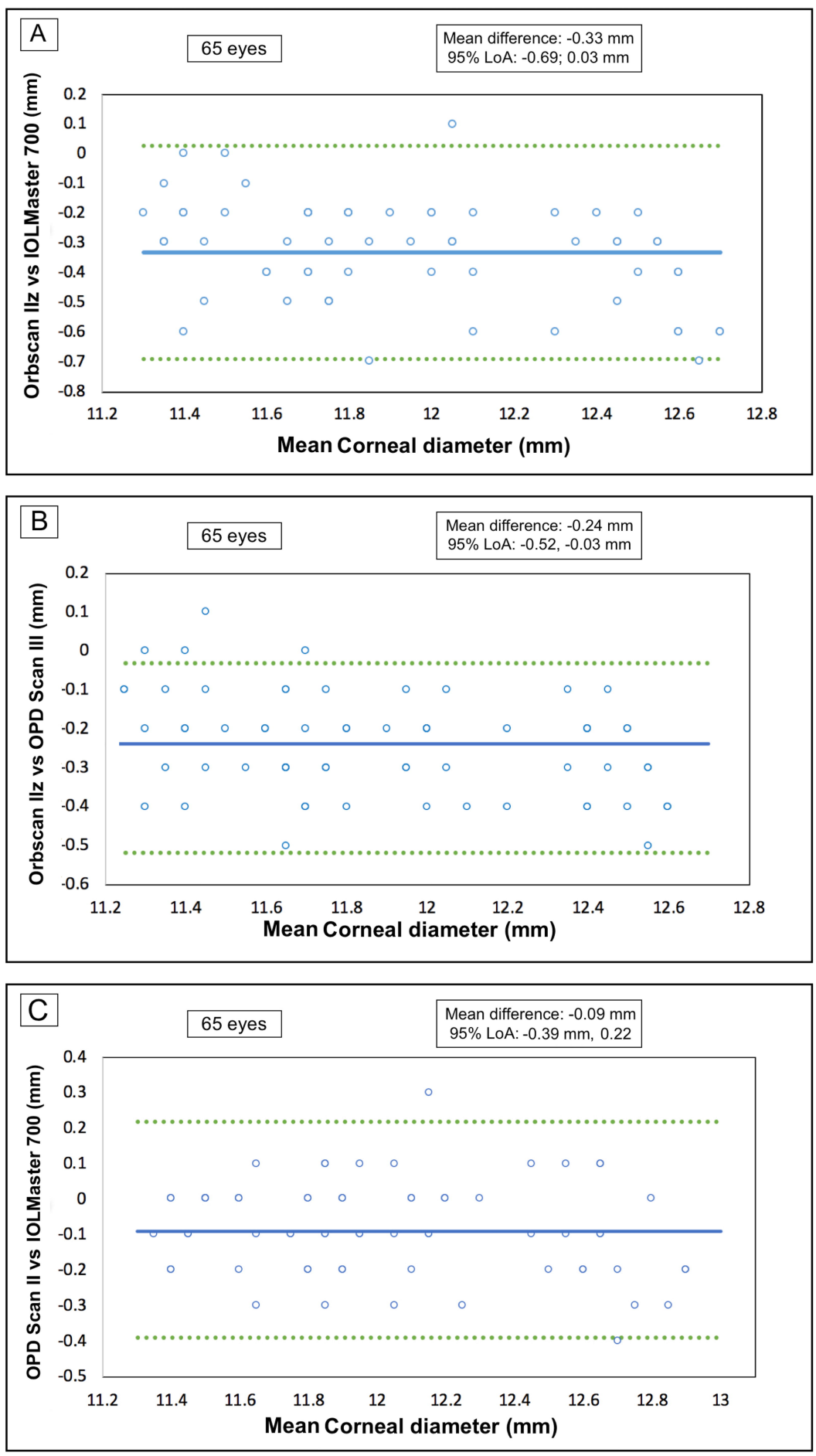

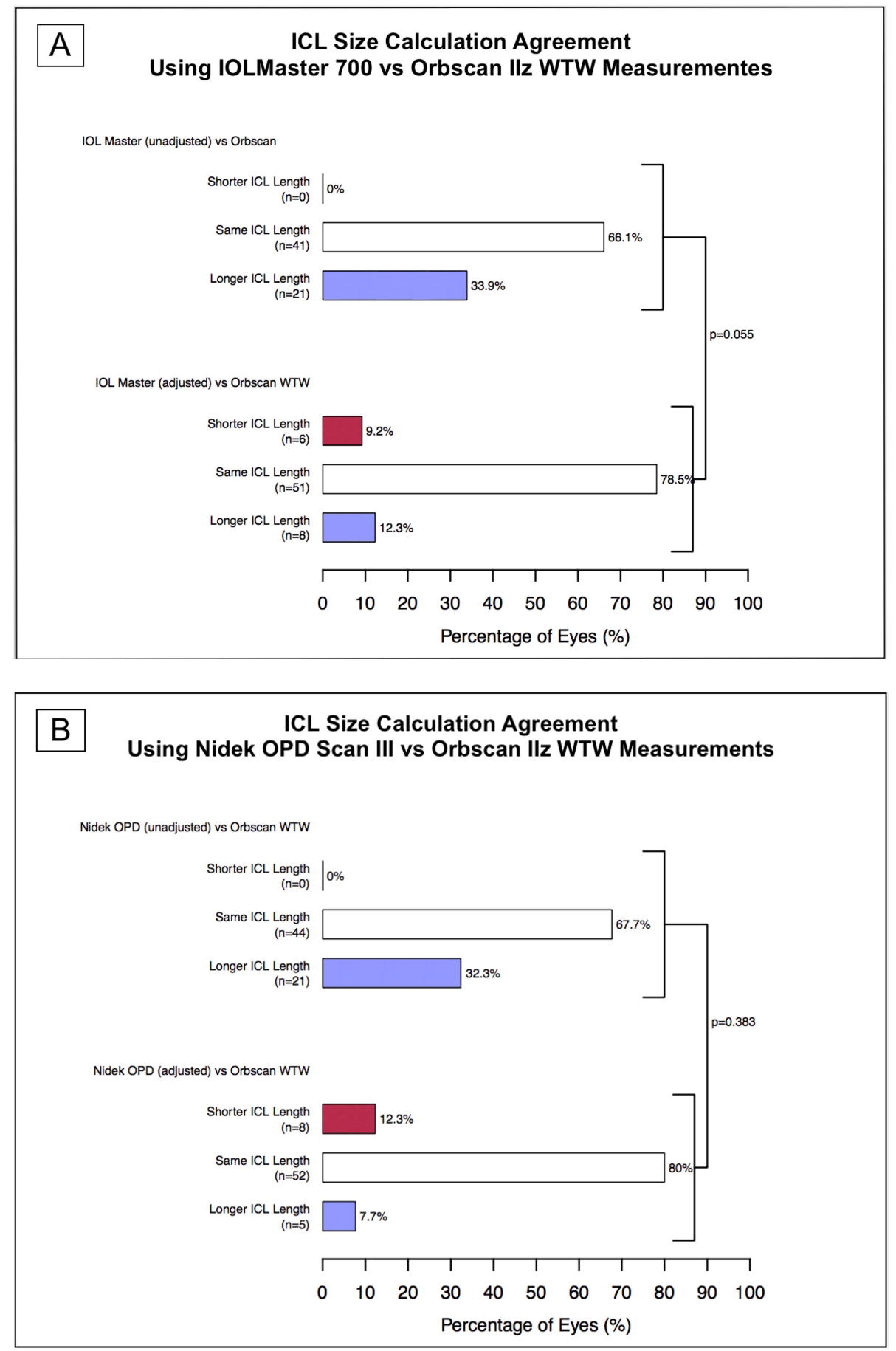